\title{
ADULT HEARING LOSS : APPLYING THE FIVE MODELS OF OSTEOPATHIC MEDICINE TO DIAGNOSE AND TREAT
}

\author{
Adel Elnashar, OMS-III'; Zachary Lodato, OMS-III'; Sheldon Yao, DO, FAAO' \\ 1.New York Institute of Technology College of Osteopathic Medicine, Old Westbury, NY
}

\author{
KEYWORDS: \\ Hearing Loss \\ Lymphatic Treatment \\ Osteopathic \\ Manipulative Medicine \\ Somatic Dysfunction
}

\begin{abstract}
:
Hearing loss is a common complaint with extensive cognitive, physical, emotional, social and financial implications. Many adults are expected to present with varying degrees of hearing loss by the age of 60 to 69 years old that can be classified according to the cause into conductive, sensorineural and mixed. There can be associated symptoms, like tinnitus, vertigo and otalgia and/or abnormal behaviors such as social withdrawal and difficulty with interpersonal communication. Somatic dysfunctions can accompany hearing troubles and range from fluid problems such as fluids accumulation in the middle ear, lymphatic congestion of the head and neck, and structural dysfunctions in the eustachian tube, neck musculature, thoracic spine, ribs and the cranial rhythmic impulse in addition to other neurologic dysfunctions such as sympathetic hyperactivity and viscerosomatic changes. In this review, we provide several suggestions that may assist the osteopathic family physician in identifying the various causes behind the hearing loss, especially life-threatening or quality-of-life limiting causes. We will also provide an effective treatment addressing the cause of the hearing loss presentation and associated somatic dysfunctions, alone or in conjunction with other appropriately trained health care providers, based on the understanding of the five models of osteopathic medicine and how they can apply toward the anatomical and physiological components of adult hearing loss.
\end{abstract}

\section{INTRODUCTION}

The auditory system is an excellent illustration of structure and function. Each type of hearing loss is associated with many etiologies that can be conductive, sensorineural and mixed. ${ }^{1}$ Conductive hearing loss will result from impedance of sound wave transmission to the inner ear. In contrast, sensorineural hearing loss occurs when the inner ear fails to transduce these waves into an electrical signal. Whereas mixed hearing loss is a combination of either type to differing degrees. ${ }^{2}$ Hearing loss is a common problem many adults will face at some point, given its strong association with aging. ${ }^{2}$ This is of utmost significance, given that different degrees of hearing loss can have substantial cognitive, emotional, social and financial effects.

The physician should take special care to be attentive to all those effects and aspects of the patient's health history and profile. The osteopathic family physician can address most hearing loss presentations, alone or in conjunction with other appropriately

\section{CORRESPONDENCE:}

Sheldon Yao, DO, FAAO | syao@nyit.edu

Copyright $\subset 2021$ by the American College of Osteopathic Family Physicians. All rights reserved. Print ISSN: 1877-573X

DOI: $10.33181 / 13012$ trained health care providers. However, osteopathic family physicians are also well suited for managing such patients' care, given their understanding of the five models of osteopathic medicine and how they can apply to adult hearing loss's anatomical and physiological components.

\section{EPIDEMIOLOGY}

Within the United States, an estimated 30 million adults have some degree of hearing loss. ${ }^{2}$ The prevalence of hearing loss increases with age, given that a remarkable $77 \%$ of adults 60 to 69 years old can be expected to have some degree of hearing loss. ${ }^{3}$ Hearing loss can hinder activities of daily living, especially in the elderly, a population more susceptible to poorer quality of life. Hearing loss has also been associated with dementia, depression, debility, delirium, falls and mortality. ${ }^{2}$ Nevertheless, improvement in life quality and physical function is attainable after amplification via cochlear implants. ${ }^{3}$

In younger age groups aging 20 to 69 years old, men are more susceptible to hearing loss and double the risk compared to females. ${ }^{4}$ Non-Hispanic white adults are more likely to suffer from hearing loss than other ethnic groups, whereas non-Hispanic black adults have the least prevalence. ${ }^{4}$ About $18 \%$ of adults who report five or more years of occupational exposure to very loud noise have speech-frequency bilateral hearing loss. ${ }^{4}$ This latter type of hearing loss can be preventable. 


\section{PATHOPHYSIOLOGY}

Hearing loss can be categorized into conductive, sensorineural and mixed hearing loss. In conductive hearing loss, the transmission of sound waves is impaired due to structural damage or an anatomical abnormality confined to the outer ear, cerumen impaction of the auditory canal and/or impairment of the ossicles found within the middle ear. ${ }^{1}$ (Table 1) For example, elderly individuals with hearing aids are at risk for developing chronic otitis externa; hearing aids promote a dark, warm and alkaline environment ideal for bacterial growth, breakdown of the cerumen barrier, inflammation and edema of the outer ear skin, which subsequently leads to impaired transmission of sound waves. ${ }^{5}$

\section{TABLE 1:}

Differential diagnoses for hearing loss

\begin{tabular}{|c|c|c|c|}
\hline CAUSE & TYPE OF HEARING LOSS & $\begin{array}{l}\text { SPECIAL TESTING } \\
\text { CONSIDERATIONS }\end{array}$ & FEATURES \\
\hline \multicolumn{4}{|l|}{ OUTER EAR } \\
\hline Otitis externa & Conductive & Otoscopy & $\begin{array}{l}\text { Associated with trauma, } \\
\text { swimming, hearing aids, other } \\
\text { dermatologic conditions (psoriasis). } \\
\text { A necrotizing type is associated } \\
\text { with diabetes mellitus and the } \\
\text { immunocompromised. }\end{array}$ \\
\hline Trauma/post-concussion syndrome & Conductive / Sensorineural / Mixed & Otoscopy & $\begin{array}{l}\text { Fractures involving the inner ear } \\
\text { will have both hearing loss and } \\
\text { vertigo components }\end{array}$ \\
\hline Cerumen & Conductive & Otoscopy & $\begin{array}{l}\text { Cerumen is much harder and } \\
\text { migrates much more slowly out of } \\
\text { the ear canal in the elderly } 1,68\end{array}$ \\
\hline Exostosis & Conductive & Otoscopy & $\begin{array}{l}\text { Firm, sessile, multinodular bony } \\
\text { masses, associated with cold water } \\
\text { exposure }^{69}\end{array}$ \\
\hline Osteoma of external ear canal & Conductive & Otoscopy & $\begin{array}{l}\text { Found along tympano-squamous } \\
\text { suture line, more medial to TM } \\
\text { versus exostoses and solitary }\end{array}$ \\
\hline Squamous cell carcinoma & Conductive & Otoscopy, CT, MRI & $\begin{array}{l}\text { Most common malignancy of EAC. } \\
\text { May be mistaken for otitis externa } \\
\text { on initial clinical inspection }{ }^{71}\end{array}$ \\
\hline \multicolumn{4}{|l|}{ MIDDLE EAR } \\
\hline Eustachian tube dysfunction & Conductive & Physical evaluation & $\begin{array}{l}\text { Can predispose adults to acute } \\
\text { otitis media and serous otitis media }\end{array}$ \\
\hline Otitis media & Conductive / Sensorineural & Otoscopy, Tympanogram & $\begin{array}{l}\text { Fluid prevents movement of the } \\
\text { tympanic membrane }^{2}\end{array}$ \\
\hline Cholesteatomata & Conductive / Sensorineural & Otoscopy, CT, MRI & $\begin{array}{l}\text { Desquamated, stratified, squamous } \\
\text { epithelium expands and erodes into } \\
\text { bony covering of the middle ear and } \\
\text { inner ear }{ }^{72}\end{array}$ \\
\hline Otosclerosis & Conductive / Sensorineural & Tympanogram & $\begin{array}{l}\text { Stapes abnormally grows and } \\
\text { eventually fixates, which leads to } \\
\text { dysfunction }{ }^{73}\end{array}$ \\
\hline TM perforation & Conductive & Otoscopy & $\begin{array}{l}\text { Usually due to trauma from foreign } \\
\text { bodies, barotrauma, acute otitis } \\
\text { media and chronic otitis media }{ }^{2}\end{array}$ \\
\hline \multicolumn{4}{|l|}{ INNER EAR } \\
\hline Presbycusis & Sensorineural & Physical evaluation & $\begin{array}{l}\text { Proposed mechanisms of injury are } \\
\text { sensory and/or metabolic }{ }^{6}\end{array}$ \\
\hline Labyrinthitis & Sensorineural & Physical evaluation & $\begin{array}{l}\text { Inflammation of the inner } \\
\text { ear labyrinth associated with } \\
\text { nystagmus, nausea and vomiting. }{ }^{2} \\
\text { Vestibular neuritis isn't associated } \\
\text { with a hearing component. }\end{array}$ \\
\hline Meniere Disease & Sensorineural/Fullness & Enhanced MRI, CT & $\begin{array}{l}\text { Mostly unilateral, endolymphatic } \\
\text { hydrops occurs secondary to } \\
\text { obstruction of the endolymphatic } \\
\text { sac or duct }{ }^{74}\end{array}$ \\
\hline
\end{tabular}




\begin{tabular}{|l|l|l|l|}
\hline Noise exposure & Sensorineural & Physical evaluation & $\begin{array}{l}\text { Can be temporary or permanent, } \\
\text { depending on the intensity and } \\
\text { duration of exposure. Proposed } \\
\text { mechanism of disease is permanent } \\
\text { loss of hair-cell ribbon synapses. }\end{array}$ \\
\hline Tumors of cerebellopontine angle & Sensorineural & Enhanced MRI, CT & $\begin{array}{l}\text { Unilateral, i.e., schwannomas, } \\
\text { meningiomas }{ }^{2}\end{array}$ \\
\hline Ototoxic substances & Sensorineural & Physical evaluation, Drug levels & $\begin{array}{l}\text { Usually bilateral, aminoglycosides, } \\
\text { salicylates, cisplatin and other toxic } \\
\text { agents to sensory hair cells }\end{array}$ \\
\hline SYSTEMATIC DISEASE & \multicolumn{3}{|l|}{} \\
\hline Cerebrovascular accident & Sensorineural & Physical evaluation, CT, MRI & $\begin{array}{l}\text { Infarction involving posterior } \\
\text { circulation usually involving the } \\
\text { anterior inferior cerebellar artery }\end{array}$ \\
\hline Multiple Sclerosis & & & $\begin{array}{l}\text { Unilateral or bilateral, transient, } \\
\text { rule out other conditions }{ }^{1}\end{array}$ \\
\hline Hypothyroidism & Sensorineural & Physical evaluation, MRI, & lumbar puncture \\
\hline
\end{tabular}

On the other hand, sensorineural hearing loss involves the cochlea, spiral ganglion neurons and more proximal auditory structures. ${ }^{1}$ Age-related hearing loss (presbycusis) is the most common and symptoms usually manifest bilaterally. At a high frequency ( $\geq 2000 \mathrm{~Hz}$ ), patients will usually experience notable hearing deficits. ${ }^{1,6}$ Another common culprit is noise exposure and this happens via two mechanisms. One mechanism is sensory and may involve mechanical stress of intense sound pressure upon the inner ear's sensory hair cells. The second mechanism is metabolic and may involve the activation of stress-induced molecular pathways, including the generation of reactive oxygen species and excessive calcium. ${ }^{1,7}$ Additionally, patients with inner ear pathology, i.e., schwannoma and Meniere's disease ${ }^{8}$, usually report tinnitus or perception of noise or ringing in the ears.

Furthermore, hearing troubles can be associated with a plethora of structural dysfunctions in the eustachian tube (ET), neck musculature, thoracic and ribs, neurologic dysfunction that may include sympathetic hyperactivity and viscerosomatic changes, and, last but not least, fluid problems such as fluids in middle ear and lymphatic congestion of head and neck. ${ }^{9}$ For example, ET dysfunction can show a poor response of tympanic membrane (TM) to insufflation, but hypertonicity in the posterior pharyngeal muscles, the medial pterygoid, and the digastric muscles and/ or dysfunction of the hyoid bone may also play an important additional role in the presenting ET dysfunction. ${ }^{10}$ Normally, the ET ventilates the middle ear with swallowing, sneezing and yawning. When the ET becomes blocked, i.e., an infection, pressure changes retract the TM. This can lead to transudate accumulation, otitis media with effusion (OME) and hearing loss.

Another dysfunction that should be investigated is related to the cranial rhythmic impulse (CRI). CRI continuous cycle of internal and external temporal rotation may assist in the ear's drainage. 11,12,13 Occipito-mastoid or spheno-squamous compression can lead to sustained internal rotation of the temporal bone; consequently, temporal bone dysfunctions can be a risk factor in cases of impaired hearing and vertigo through maintaining partial or complete closure of the ET. Unilateral internal rotation temporal dysfunction has been reported with otitis media in children and adults. ${ }^{14}$ Various osteopathic manipulative techniques have been shown to be beneficial in treating patients with otitis media. ${ }^{15,16,17}$

\section{STRUCTURAL CONSIDERATIONS}

The temporal bone's petrous portion encases the middle ear and amplifies the sound waves received through the tympanic membrane via the bony ossicles. ${ }^{18}$ The ET controls the pressure inside the middle ear and connects it to the lateral nasopharynx. Ciliated epithelial cells continuously deliver secretions from the middle ear to the nasopharynx. The ET has a lateral bony part fashioned by the petrous bone and the greater sphenoid wing and a medial cartilaginous part. Pharyngeal muscles, namely the Tensor veli palatini and salpingopharyngeus muscles, open the ET, while the levator veli palatini muscle and the palatine aponeurosis act to elevate the soft palate to seal the nasopharynx from the oropharynx when needed. An additional muscle worth mentioning is the sternocleidomastoid (SCM) muscle, which attaches to the mastoid process of the temporal bone, and the temporomandibular joint (TMJ) located anterior to the ear. ${ }^{10,19}$

The TMJ is a hinge joint formed by the head of the mandible and mandibular fossa of the temporal bone separated by a fibrocartilagenous articular disc. The lateral pterygoid muscle is attached to open the mouth. ${ }^{20,21}$ The suprahyoid muscles, mylohyoid, geniohyoid and digastric muscles, open the mouth via a hinge-like movement, while the lateral pterygoid muscles provide a simultaneous anterior glide movement. The temporalis, masseter and medial pterygoid muscles close the mouth. Patients with TMJ dysfunction can find it difficult to open their mouth fully accompanied by a mandible shift to the side of dysfunction.

Sympathetic supply to the ear originates from spinal levels at T1-T4 accompanying the arterial supply, trigeminal nerve and gray rami communicate $\mathrm{C} 1-\mathrm{C} 2.2^{2,23}$ Sympathetic visceral afferent nerves and the trigeminal nerve convey somatovisceral reflexes to the structures of the head and neck and muscles of mastication and high cervical paraspinal musculature. ${ }^{24}$ The facial nerve conveys the chorda tympani parasympathetic supply via the pterygopalantine ganglion to the ear, the upper respiratory tract, eye, palatine, submandibular and sublingual glands. ${ }^{25,26}$ The facial nerve chorda tympani and its motor division run through the temporal bone's internal auditory meatus accompanied by the vestibulocochlear nerve. ${ }^{27}$ Facial nerve parasympathetic fibers reach their target organs via the trigeminal, as well as the high cervical gray rami communicates. ${ }^{28,29,30,31}$ Parasympathetic 
innervation, motor innervation to the muscles of mastication, especially temporalis muscle and innervation to the high cervical paravertebral region carry parasympathetic viscerosomatic reflexes to different head and neck regions. Preauricular and postauricular lymph nodes receive lymphatic drainage from the ear, then drains through the thoracic inlet to the thoracic duct and right lymphatic duct.

\section{CLINICAL EVALUATION}

Patients will normally present with hearing impairment that is self-recognized and/or by others around them. There may be associated behaviors such as social withdrawal and difficulty with interpersonal communication. Sometimes there will be various associated symptoms, like tinnitus, vertigo and otalgia, which can be associated with specific SDs. (Table 2) Ask about the duration and laterality of hearing loss and whether it's fluctuating or progressive. Consider depression and dementia as a differential for hearing loss $^{2}$ and how age may impact hearing loss prevalence. The physician should take a holistic approach and adequately examine these complaints in addition to screening related anatomy and systems, i.e., posterior pharynx, medial pterygoid, cranium, TMJ, cervical and thoracic spine ribs, and TM insufflation. Ear position can be examined during the standing structural exam. Pain elicited from pulling on the pinna gently upward and posteriorly indicates otitis externa. Hypertonia in the cervical myofascial tissues can interfere with the lymphatic flow ${ }^{32}$ and should also be excluded. Look for signs of inflammation that involves the ear and using otoscopy examine inner ear structure. The TM normally should be pearly white. Second, evaluate for motion by insufflation or a tympanogram. A hearing test is appropriate for specific complaints and suspected occupational troubles.
The SCREAM mnemonic stands for sudden hearing loss, cerumen impaction, auditory rehabilitation, education, assistive devices and medications. ${ }^{2}$ (Table 3) According to SCREAM, if the patient was identified to have sudden idiopathic during clinical evaluation or suspected to be suffering from presbycusis, audiometry can confirm the hearing loss finding. If not emergent, consultation with an otolaryngologist should occur within one week. Yet given the many possible pathologies responsible for the different hearing loss types (Table 1), one must consider a broad differential and know who to consult appropriately.

The whispered voice test and tuning fork are common methods to diagnose hearing loss. ${ }^{33,34}$ The former can screen hearing status; the latter can investigate the type and laterality of hearing loss if existent. In a normal Weber tuning fork test, the sound should be heard equally on both sides, but that can also be true if hearing loss is symmetrical. The Rinne tuning fork test can identify conductive hearing loss if the vibrating fork is heard louder when placed on the mastoid process contrasted with next to the ear. A prevalent cause for conductive hearing loss in adults is cerumen impaction. Patients might present with a persistent nonproductive cough if cerumen irritates the auricular branch of the vagus nerve or appear withdrawn and relatively unresponsive if the cerumen impaction cause diminished hearing.

Chapman's points, palpable tender sharp pinpoint nodular masses, if existent, can be used to facilitate diagnosis. Posterior Chapman tender points for middle ear infections may be found at the posterior aspect of the tip of the first cervical vertebra's transverse process. ${ }^{35}$ In contrast, anterior Chapman tender points are located on the upper edge of the proximal clavicle as it crosses over the first rib. Table 4 lists Chapman points associated with head and neck structures. ${ }^{36}$

\section{TABLE 2:}

Symptoms associated with hearing loss

\begin{tabular}{|l|l|}
\hline $\begin{array}{l}\text { HEARING LOSS } \\
\text { ASSOCIATED SYMPTOMS }\end{array}$ & POTENTIAL DYSFUNCTIONS \\
\hline Tinnitus & $\begin{array}{l}\text { - ER temporal bone, especially low pitched roaring noises } \\
\text { - IR temporal bone, especially high pitched roaring noises } \\
\text { - Temporomandibular disorders }\end{array}$ \\
\hline Vertigo & $\begin{array}{l}\text { - ER temporal bone } \\
\text { - IR temporal bone }\end{array}$ \\
\hline Referred Otalgia & $\begin{array}{l}\text { - Dysfunctions from the teeth, tongue, tonsils, esophagus } \\
\text { - TMJ dysfunction } \\
\text { - Referred from cranial nerves V, IX and X } \\
\text { - C1-2 spinal segments dysfunction } \\
\text { - Trauma } \\
\text { - TMJ joint inflammation } \\
\text { - Dysfunctions of the head, neck and upper back regions } \\
\text { - Stress, depression and fatigue } \\
\text { - Habits such as gum and ice chewing }\end{array}$ \\
\hline Malocclusion, Bruxism, jaw clenching 77 & $\begin{array}{l}\text { - TMJ dysfunction } \\
\text { - Trigger points (especially in the pterygoids, masseter and digastric muscles) } \\
\text { - Cranial dysfunctions } \\
\text { - Stress-induced general muscle hypertonicity }\end{array}$ \\
\hline
\end{tabular}


TABLE 3:

SCREAM mnemonic

\begin{tabular}{|c|c|c|}
\hline CONCERN & DESCRIPTION & EVALUATION \\
\hline Sudden hearing loss & $\begin{array}{l}\geq 30 \mathrm{~dB} \text { hearing loss at three consecutive } \\
\text { frequencies over } 72 \text { hours }\end{array}$ & $\begin{array}{l}\text { Rule out conductive hearing loss or a } \\
\text { readily identifiable cause }\end{array}$ \\
\hline Cerumen impaction & Occlusive cerumen & Perform otologic examination \\
\hline Auditory rehabilitation & Improve hearing environment & $\begin{array}{l}\text { Assess patient's and family's current } \\
\text { knowledge and habits }\end{array}$ \\
\hline Assistive devices & $\begin{array}{l}\text { Technology to augment hearing, including } \\
\text { over-the-counter devices }\end{array}$ & $\begin{array}{l}\text { Determine whether the patient is a } \\
\text { candidate for over-the-counter devices or } \\
\text { if audiological testing for hearing aids is } \\
\text { necessary }\end{array}$ \\
\hline Medications & $\begin{array}{l}\text { Evaluating and mitigating medications with } \\
\text { toxicity }\end{array}$ & $\begin{array}{l}\text { Determine the patient's current and past } \\
\text { use of ototoxic medications }\end{array}$ \\
\hline
\end{tabular}

TABLE 4:

Chapman tender points for HEENT

\begin{tabular}{|c|c|c|}
\hline CHAPMAN TENDER POINTS & STRUCTURE & LOCATION \\
\hline \multirow[t]{5}{*}{ Anterior } & Nasal sinuses & $\begin{array}{l}\text { Bilaterally } 7 \text { to } 9 \mathrm{~cm} \text { lateral to the sternum } \\
\text { on the upper edge of the second ribs }\end{array}$ \\
\hline & Pharynx & $\begin{array}{l}\text { The first ribs } 3 \text { to } 4 \mathrm{~cm} \text { medial to where the } \\
\text { ribs emerge from beneath the clavicles }\end{array}$ \\
\hline & Larynx & $\begin{array}{l}\text { The second ribs, } 5 \text { to } 7 \mathrm{~cm} \text { lateral } \\
\text { to the sternocostal junction }\end{array}$ \\
\hline & Tonsil & $\begin{array}{l}\text { Between the first and the second ribs } \\
\text { adjacent to the sternum }\end{array}$ \\
\hline & Middle ear & $\begin{array}{l}\text { The superior/anterior aspect of the clavicles } \\
\text { just lateral to where they cross the first ribs }\end{array}$ \\
\hline \multirow[t]{3}{*}{ Posterior } & Posterior nasal sinuses, pharynx and larynx & $\begin{array}{l}\text { C2, midway between the spinous process } \\
\text { and the tip of the transverse process }\end{array}$ \\
\hline & Tonsil & $\begin{array}{l}\text { C1 midway between the spinous process } \\
\text { and the tip of the transverse process }\end{array}$ \\
\hline & Middle ear & $\begin{array}{l}\text { Posterior aspect of the tips of transverse } \\
\text { processes of C1 }\end{array}$ \\
\hline
\end{tabular}

ET dysfunction can result from a variety of dysfunctions, i.e., myofascial trigger points (MTrPs) in the medial pterygoid muscle (Table 5), vagus nerve, IR temporal, torsion, side bending of SBS (sphenobasilar symphysis). ${ }^{37,38}$ Certain disorders, for example, Meniere's disease, can be associated with specific temporomandibular, craniomandibular and cervical spine SD and can be linked to specific somatic movements. ${ }^{39,40,41}$ 
TABLE 5:

Myofascial trigger points (MTrPs)

\begin{tabular}{|c|c|c|}
\hline SOMATIC DYSFUNCTION & MTrPs TECHNIQUE & POTENTIAL TREATMENT TARGETS \\
\hline $\begin{array}{l}\text { Travell trigger with EENT } \\
\text { symptoms } s^{37,79}\end{array}$ & $\begin{array}{l}\text { - Deep portion of masseter } \\
\text { (upper most posterior angle of } \\
\text { the masseter) } \\
\text { - SCM clavicular head } \\
\text { - Medial pterygoid } \\
\text { - Occipitalis, according } \\
\text { to Kellgren }\end{array}$ & - Ear pain, tinnitus and/or diminished hearing \\
\hline ET dysfunction & - Medial pterygoid & - Ear fullness, unilateral tinnitus and hearing loss \\
\hline TMJ disorders & $\begin{array}{l}\text { - Masseter } \\
\text { - Pterygoids } \\
\text { - SCM clavicular head } \\
\text { - Occipitalis } \\
\text { - Digastric }\end{array}$ & $\begin{array}{l}\text { - Dysfunction of eye, ear, nose and throat } \\
\text { - Deep ear pain } \\
\text { - Hearing loss }\end{array}$ \\
\hline Low roaring tinnitus & - Masseter & Can vary when jaw is opened \\
\hline Ear stiffness & - Medial pterygoid & $\begin{array}{l}\text { Inability of tensor veli palatine to move medial pterygoid and associated fascia and } \\
\text { open } \mathrm{ET}^{10,30}\end{array}$ \\
\hline
\end{tabular}

Furthermore, the physician should seek to identify any possible increased number of cranial strain patterns. ${ }^{42}$ Cranial vault hold can assess the primary respiratory mechanism and general cranial movement ${ }^{30,43,44}$ and identify temporal bone dysfunction, unilateral or bilateral. Temporal bones closely relate to one another and the skull base's midline bones, the sphenoid and the occiput. A protruding ear may indicate an externally rotated temporal bone. The temporal bones externally rotate accompanied by sphenooccipital flexion and internally rotate with extension. The physician should also look for SCM hypertonicity, which may facilitate a dysfunctional internal rotation of the temporal bone. ${ }^{10}$

On the other hand, a fronto-occipital hold is particularly useful when assessing the SBS. For instance, the restriction of temporal external rotation could suggest the SS pivot's motion restriction, a common finding with ENT complaints such as ear pain and jaw pain. It may result from the medial or lateral pterygoid muscle's facilitation, which crosses the suture at its bevel and refer pain to the ear and face. ${ }^{45}$ Another example is unilateral petrojugular synchondrosis motion restriction commonly associated with vertigo suggested by the paradoxical motion of a temporal bone (the temporal moves into internal rotation with occipital flexion). Anterior occiput dysfunction and anterior atlas dysfunction produce ipsilateral pain in the region of the ear and behind the eye, respectively. ${ }^{28}$ Upper respiratory symptoms may result from dysfunction involving the base of the skull and face.

\section{TREATMENT}

An osteopathic approach should be used to holistically address the patients' body, mind and soul and investigate their specific nutritional needs and functional capacity. Next, the physician should consider all possible diagnoses and take adequate time to discuss risk factors and patients' treatment plans. Moreover, the physician should separate causes that can be life-threatening or limit life quality to a great degree. Effective treatment will be directed towards the cause behind the hearing loss and associated somatic dysfunctions (SDs). For example, a counterstrain technique is preferred if pterygoid muscles trigger points aren't the cause behind the TMJ, SD and will be more effective in opening the ET. On the other hand, a Galbreath technique may aggravate the joint in such a scenario and better be avoided.

Osteopathic manipulative treatment (OMT), including those intended for prevention, should be integrated with simultaneously disease-focused approaches to hearing loss to yield the greatest benefit. Previously the otolaryngologist Teachey found that MTrPs were responsible for over $40 \%$ of complaints in a series of 250 patients whose complaints varied between pain, headaches or ear, nose, throat symptoms. ${ }^{46}$ MTrPs can be aggravated with cold and emotional stress. When treated, they can help in complaints such as hyperacusis, hypoacusis, auricular FB sensation, "blocker" ears, hearing loss, tinnitus and dizziness with normal otolarnygic and audiometric studies. (Table 5)

OMT should address structural, autonomic and fluid aspects of the dysfunction. Generally soft tissue techniques, i.e., muscle energy, soft tissue stretching, myofascial release, are most suitable for dysfunctions due to soft tissue tension. Myofascial dysfunction in pharyngeal and laryngeal muscles can again respond well to OMT, like the Galbreath technique. Normally these muscles are responsible for yawning and swallowing that open the eustachian tubes and are innervated by glossopharyngeal and vagus nerves. Finger surgery, a direct digital technique, can release nasopharyngeal adhesions around the eustachian tubes through its direct gentle pumping action. ${ }^{47}$ Eustachian tube dysfunction can predispose to otitis media, especially in children whose ET is shorter and more horizontal than adults. ${ }^{48,49,50}$ ET dysfunction responds well to the treatment of SDs affecting the cranium, cervical and thoracic spine, medial pterygoid muscle, cervical fasciae and sacrum. Extensive OMT involving the diaphragm, pelvis and even the lower extremities, may be required in select cases. 
The sympathetic component in the form of facilitated thoracic dysfunction or Chapman's points should also be addressed. Posterior Chapman's points should be treated first and then residual tender anterior points can be gently treated with soft tissue. Counterstrain and facilitated positional release are the best options to reduce neural reflex activity. High-velocity lowamplitude thrust (HVLA) and low-velocity/moderate-to-highamplitude articulation procedures may address dysfunctional articular mechanics. OMT sessions should be spaced out, and its amount increased incrementally, according to the patients' response, especially for slow responders ${ }^{51}$, i.e., elderly, to prevent a rebound reaction OMT. Acceptable rebound reaction can typically last 12-48 hours after the first or second treatment. It can vary from slight fatigue to an intensified sense of pain and can readily be produced by soft tissue techniques.

OMT can be specifically beneficial and cost-saving for challenging diseases like Meniere's diseases, ${ }^{52}$ whose patients may seek benefits from complementary and alternative approaches..$^{53,54,55}$ Korr et al. revealed an improvement in 79\% of Meniere's patient's cases treated with OMT. ${ }^{56}$ Adamek K. et al. demonstrated a significant impact on various symptoms like hearing loss, vertigo, aural fullness and tinnitus with three weekly visits. ${ }^{57}$ Even in comparable scenarios that seems to preclude improvement with OMT, the biopsychosocial model can still be utilized to relieve anxiety, stress and tension. Hereby, we will list several specific osteopathic considerations regarding osteopathic models that may be addressed when managing a patient with hearing loss.

\section{Biomechanical model considerations}

The physician can initiate his treatment with various soft tissue techniques to induce patient relaxation and reduce patients' guarding during further OMT and promote the doctor-patient relationship. Soft tissue techniques, such as suboccipital release, supine traction and various fulcrum techniques, can promote circulation to the region by local physical and thermodynamic effects or somatic-somatic or somato-visceral reflexes to improve circulation in a distal area. Venous and lymphatic drainage can be potentially induced to reduce local and/or distal swelling and edema and boost immune response, local tissue nutrition, oxygenation and removal of metabolic wastes. Like in all other OMT, dexterity holds the utmost significance. For example, when performing traction techniques in patients with TMJ dysfunctions, place your hands on the forehead instead of the mandible.

\section{Respiratory-circulatory model considerations}

Lymphatic techniques should be used in a stepwise fashion to address associated thoracic/costal, upper lumbar SDs or lymphatic congestion in the ENT region. (Table 6) For example, myofascial release (MFR) techniques can be used to release thoracic inlet myofascial restrictions. Muscle energy techniques (MET) can be directed at the cervicothoracic junction as well. Cervical MET may improve local circulation and respiratory function. 58,59,60,61

Additionally, a post-isometric relaxation technique can be used to address trapezius muscle hypertonicity, SCM dysfunction and cervical SD. Reciprocal inhibition is useful for any associated SCM spasm (acute torticollis). Acute oculocephalogyric reflex, another MET, can be combined with any of the cervical METs.
Second, balanced ligamentous tension (BLT) and ligamentous articular strain techniques can also address lymphatic congestion or local edema in the cervical region, i.e., occipitoatlantal (OA, C0-C1) dysfunction, atlantoaxial (AA, C1-C2) dysfunction, C2-C7 dysfunctions. ${ }^{30,62,63,64}$ Third, articulatory and combined techniques can address both the circulatory and lymphatic congestion and articular and myofascial SDs arising from the restricted motion of C2-C7 dysfunctions. ${ }^{30,65,66}$ Articulatory techniques are particularly useful in the frail or elderly. In cases of hearing loss, OMT can address both the ear and associated SDs, i.e., sinusitis. Reevaluate the cervical range of motion (ROM) and TART diagnostic parameters of the dysfunction to determine the technique's effectiveness. Decreased muscle tone and improved body carriage are signs of successful treatment.

\section{Neurological model considerations}

Cranial manipulative techniques are indicated in common complaints from patients with hearing loss such as headaches, vertigo and tinnitus, otitis media with effusion and serous otitis media, TMJ dysfunction and sinusitis. (Table 7) Throughout OMT, continuously note the amplitude, rate and regularity of the CRI. Techniques directed at cranial dysfunctions aim to synchronize cranial torsions, temporal bone external and internal rotations, normalizing flexion and extension of the sphenobasilar symphysis and removing areas of dural strain. ${ }^{67}$

\section{CONCLUSION}

Hearing loss in adults has a wide range of causes and can be a common presentation for the osteopathic family physician. Identifying the specific cause behind the hearing loss should be the first step towards effective, successful management. After excluding serious conditions, adjunct OMT can be a useful addition to a complete holistic approach. The five osteopathic models can address the causes precipitating the presenting condition, associated dysfunctions and disability, and preventive measures.

\section{AUTHOR DISCLOSURE(S):}

No relevant financial affiliations or conflicts of interest. If the authors used any personal details or images of patients or research subjects, written permission or consent from the patient has been obtained. This work was not supported by any outside funding. 
TABLE 6:

Lymphatic techniques ${ }^{82,83}$

\begin{tabular}{|c|c|c|}
\hline TECHNIQUES & SOMATIC DYSFUNCTION & POTENTIAL TREATMENT EFFECTS \\
\hline - Thoracic inlet fascial release & $\begin{array}{l}\text { - Clavicular SD } \\
\text { - Upper thoracic SD } \\
\text { - Ribs SD }\end{array}$ & $\begin{array}{l}\text { - Reduce sympathetic facilitation upon the head and neck } \\
\text { - Improve respiratory motion } \\
\text { - Improve lymphatic drainage }\end{array}$ \\
\hline $\begin{array}{l}\text { - Myofascial release } \\
\text { - Counterstrain } \\
\text { - Still technique } \\
\text { - Muscle energy } \\
\text { - High-velocity, low-amplitude } \\
\text { (HVLA) }\end{array}$ & $\begin{array}{l}\text { - Upper thoracic SD } \\
\text { - Ribs SD }\end{array}$ & $\begin{array}{l}\text { - Reduce sympathetic facilitation to head and neck } \\
\text { - Improve lymphatic drainage }\end{array}$ \\
\hline $\begin{array}{l}\text { - Myofascial release } \\
\text { - Counterstrain } \\
\text { - Still technique } \\
\text { - Muscle energy }\end{array}$ & $\begin{array}{l}\text { - Anterior neck dysfunction } \\
\text { - Laryngitis } \\
\text { - Pharyngitis } \\
\text { - Anterior cervical arches } \\
\text { - Cough }\end{array}$ & $\begin{array}{l}\text { - Address hyoid, omohyoid, SCM, anterior vertebral dysfunctions } \\
\text { - Improve lymphatic drainage } \\
\text { - Decrease tension on the eustachian tubes }\end{array}$ \\
\hline $\begin{array}{l}\text { - Still technique } \\
\text { - Muscle energy }\end{array}$ & - Cervical spine SD & - Address mechanical, sympathetic and fluid components \\
\hline $\begin{array}{l}\text { - Ruddy's resistive duction } \\
\text { techniques }\end{array}$ & - General congestion & $\begin{array}{l}\text { - Relieve symptoms } \\
\text { - Decrease general swelling by use of muscular pumps } \\
\text { to move lymphatic fluids from areas of congestion }\end{array}$ \\
\hline $\begin{array}{l}\text { - Fronto (facial) temporomandibular } \\
\text { drainage \& effleurage }\end{array}$ & $\begin{array}{l}\text { - Frontal region } \\
\text { - Mandibular region }\end{array}$ & $\begin{array}{l}\text { - Relieve symptoms } \\
\text { - Improve lymphatic drainage }\end{array}$ \\
\hline • Cervical chain drainage (“milking”) & $\begin{array}{l}\text { - Ear region } \\
\text { - Otitis media } \\
\text { - Otitis externa }\end{array}$ & $\begin{array}{l}\text { - Improve lymphatic drainage } \\
\text { - Do not perform directly over painful, indurated lymph nodes }\end{array}$ \\
\hline - Traction on the pinna & $\begin{array}{l}\text { - Ear region } \\
\text { - Otitis externa }\end{array}$ & $\begin{array}{l}\text { - Improve function of the eustachian tube } \\
\text { - Decongest the middle ear } \\
\text { - Involve an abrupt application of force that can be very painful, } \\
\text { more appropriate for adults than for children }\end{array}$ \\
\hline - Auricular drainage & $\begin{array}{l}\text { - Ear region } \\
\text { - Otitis media } \\
\text { - Otitis externa }\end{array}$ & $\begin{array}{l}\text { - Relieve symptoms } \\
\text { - Improve lymphatic drainage }\end{array}$ \\
\hline $\begin{array}{l}\text { - Galbreath technique (mandibular } \\
\text { drainage) } 80,81 \\
\text { - Muncie finger surgery }\end{array}$ & - ET dysfunction & $\begin{array}{l}\text { - Stretch the medial pterygoid muscles and overlying fascia } \\
\text { - Encourage eustachian tube opening } \\
\text { - Drain the eustachian tube } \\
\text { - Care must be taken in patients with active TMJ dysfunction } \\
\text { (e.g., painful click) with severe loss of mobility and/or locking }\end{array}$ \\
\hline $\begin{array}{l}\text { - Submandibular release } \\
\text { - Suboccipital release }\end{array}$ & $\begin{array}{l}\text { - Tongue } \\
\text { - Salivary glands } \\
\text { - Lower teeth } \\
\text { - TMJ SD }\end{array}$ & $\begin{array}{l}\text { - Relieve symptoms } \\
\text { - Enhance fluid drainage } \\
\text { - Restores normal vagal tone } \\
\text { - Address spasm and hypertonicity of the cranial base }\end{array}$ \\
\hline - Maxillary drainage, effleurage & - Maxillary sinus & $\begin{array}{l}\text { - Myofascial massage to stimulate drainage of the } \\
\text { surrounding tissues, relieve pressure within the sinus }\end{array}$ \\
\hline $\begin{array}{l}\text { - Alternating nasal pressure/ } \\
\text { frontonasal distraction }\end{array}$ & - Ethmoid sinus & $\begin{array}{l}\text { - Myofascial massage help stimulate drainage of the surrounding } \\
\text { tissues to relieve pressure within the sinus }\end{array}$ \\
\hline $\begin{array}{l}\text { - Trigeminal stimulation technique } \\
\text { \& effleurage }\end{array}$ & $\begin{array}{l}\text { - Trigeminal nerve } \\
\text { - Supra orbital, infra orbital \& } \\
\text { submental foramina }\end{array}$ & $\begin{array}{l}\text { - Thinning of the secretions } \\
\text { - Constriction of the vessels allowing for increase in sinuses drainage }\end{array}$ \\
\hline
\end{tabular}


TABLE 7:

Neurologic model osteopathic manipulative treatments

\begin{tabular}{|c|c|c|}
\hline TECHNIQUE & SOMATIC DYSFUNCTION & POTENTIAL TREATMENT EFFECTS \\
\hline - Unilateral temporal rocking & $\begin{array}{l}\text { - External or internal temporal } \\
\text { rotation }\end{array}$ & - Treat temporal external/internal rotation SD \\
\hline • Temporal BMT & - Externally rotated temporal bone & $\begin{array}{l}\text { - Address low pitched roaring tinnitus } \\
\text { - Address dural strains, lack of motion and swelling } \\
\text { - Address dry eyes, reduced salivation and hyperacusis }\end{array}$ \\
\hline - OA and/or vagus & - Temporal bone dysfunction & - Address unilateral tinnitus and hearing loss \\
\hline - Sutural spread & - Restricted cranial sutures & - Release a restricted cranial suture (i.e., occipitomastoid suture) \\
\hline $\begin{array}{l}\text { - Compression of the } \\
\text { fourth ventricle }\end{array}$ & $\begin{array}{l}\text { - Parasympathytic outflow, pain, } \\
\text { anxiety }\end{array}$ & $\begin{array}{l}\text { - Augment the healing capabilities of the patient } \\
\text { - Relax the patient } \\
\text { - Improve the motion of the CRI }\end{array}$ \\
\hline $\begin{array}{l}\text { - Sphenopalatine ganglion } \\
\text { procedure and effleurage }\end{array}$ & - Pterygoid fossa congestion & $\begin{array}{l}\text { - Improve autonomic and fluid functions } \\
\text { - Decongests pterygoid fossa indirectly } \\
\text { - Normalize the function of the eustachian tube } \\
\text { - Relax the medial pterygoid muscle } \\
\text { - Enable the tensor veli palatini muscle to functionally open } \\
\text { the eustachian tube }\end{array}$ \\
\hline $\begin{array}{l}\text { - Counterstrain to medial } \\
\text { pterygoid (jaw angle point) } \\
\text { \& Masseter } \\
84,85,86\end{array}$ & - Head/cranium and/or cervical region & - Target pain in the neck, face, jaw, ear or temporomandibular joint ${ }^{85,87}$ \\
\hline $\begin{array}{l}\text { - Counterstrain to midline PC3 } \\
\text { spinous process }\end{array}$ & - Cervical spine & - Aim at suboccipital headache, earache, tinnitus and/or vertigo ${ }^{85,87,88}$ \\
\hline - Posterior Chapman's points & - Sympathetic outflow & $\begin{array}{l}\text { - Improve reflexes to and from the head, eyes, ears, nose and throat } \\
\text { - Modify sympathetic outflow }\end{array}$ \\
\hline $\begin{array}{l}\text { - Sacral and/or coccyx SD } \\
\text { techniques } \\
\text { - Vibratory percussion hammer } \\
\text { techniques }\end{array}$ & - Ganglion impar dysfunction & $\begin{array}{l}\text { - Release the ganglion impar to optimally function and communicate with } \\
\text { thoracic sympathetic chain } \\
\text { - Release tension in the cervical and upper thoracic spine due to sacral } \\
\text { and/or coccygeal restrictions } \\
\text { - Help with associated chronic otitis media }\end{array}$ \\
\hline
\end{tabular}




\section{REFERENCES:}

1. Cunningham LL, Tucci DL. Hearing Loss in Adults. New England Journal of Medicine. 2017; 377(25):2465-2473. doi:10.1056/nejmra1616601

2. Michels TC, Duffy MT, Rogers DJ. Hearing Loss in Adults: Differential Diagnosis and Treatment. American Family Physician. https://www.aafp. org/afp/2019/0715/p98.html. Published July 15, 2019. Accessed April 27, 2020.

3. Mahboubi HW, Lin HW, Bhattacharyya NW. Prevalence, Characteristics, and Treatment Patterns of Hearing Difficulty in the U.S.. JAMA Otolaryngology-Head \& Neck Surgery. 2017:65-70. doi:10.1001/ jamaoto.2017.2223

4. Hoffman HJ, Dobie RA, Losonczy KG, Themann CL, Flamme GA. Declining Prevalence of Hearing Loss in US Adults Aged 20 to 69 Years. JAMA Otolaryngology-Head \& Neck Surgery. 2017;143(3):274-285. doi:10.1001/jamaoto.2016.3527

5. Osguthorpe D, Nielsen DR. Otitis Externa: Review and Clinical Update. American Family Physician. https://www.aafp.org/afp/2006/1101/p1510. html. Published November 1, 2006. Accessed April 27, 2020.

6. Allen PD, Eddins DA. Presbycusis phenotypes form a heterogeneous continuum when ordered by degree and configuration of hearing loss. Hearing Research. 2010; 264(1-2):10-20. doi:10.1016/j. heares.2010.02.001

7. Sha SH, Schacht J. Emerging therapeutic interventions against noiseinduced hearing loss. Expert Opinion on Investigational Drugs. 2016; 26(1):85-96. doi:10.1080/13543784.2017.1269171

8. Esmaili AA, Renton J. A review of tinnitus. Australian Journal of General Practice. 2018; 47(4):205-208. doi:10.31128/ajgp-12-17-4420

9. Kuchera M, Kuchera W. Osteopathic Considerations in Systemic Dysfunction. 2nd ed. Columbus, OH: Greyden Press; 1994:2.

10. Centers S, Morelli MA, Vallad-Hix C, et al. General pediatrics. In: Ward RC, exec.ed. Foundations for Osteopathic Medicine. 2nd ed. Philadelphia, PA: Lippincott Williams \& Wilkins; 2003:305-326.

11. King HH, Lay E. Osteopathy in the cranial field. In: Ward RC, exec.ed. Foundations for Osteopathic Medicine. 2nd ed. Philadelphia, PA: Lippincott Williams \& Wilkins; 2003:985-1001.

12. Nelson KE, Sergueef N, Lipinski CM, et al. Cranial rhythmic impulse related to the Traube-Hering-Mayer oscillation: comparing laser-Doppler flowmetry and palpation. J Am Osteopath Assoc. 2001;101(3):163-173.

13. Sergueef N, Nelson KE, Glonek T. The effect of cranial manipulation upon the Traube-Hering-Meyer oscillation as measured by laser-Doppler flowmetry. Altern Ther Health Med. 2002;8(6):74-76.

14. David B. Fuller. CHAPTER 21: The Patient with Otitis Media. Somatic Dysfunction in Osteopathic Family Medicine, 2e. Wolters Kluwer, 2015.

15. Chanell MK, Mason DC. Otitis Media/Serous/Infectious. The 5-Minute Osteopathic Manipulative Medicine Consult, 2e. Wolters Kluwer, 2020.

16. Mills MV, Henley CE, Barnes LL, et al. The use of osteopathic manipulative treatment as adjuvant therapy in children with recurrent acute otitis media. Arch Pediatr Adolesc Med. 2003;157(9):861-866.

17. Shaw HH, Shaw MB. Osteopathic management of ear, nose, and throat disease. In: Ward RC, exec.ed. Foundations for Osteopathic Medicine. 2nd ed. Philadelphia, PA: Lippincott Williams \& Wilkins; 2003:370-382.

18. Agur AMR. Grant's Atlas of Anatomy. 9th Ed. Baltimore, MD: Internal structures of the ear. Williams \& Wilkins, 1991:534.

19. Steele KM. Clinical management of chronic otitis media/Eustacian tube dysfunction. Lecture presented at: Annual Convocation of the American Academy of Osteopathy; 2004; Colorado Springs, CO.

20. Larson NJ. Osteopathic manipulative contribution to treatment of TMJ syndrome. Osteopath Med 1978;10(8):16-26.
21. Nelson KE, Glonek TG. Somatic Dysfunction in Osteopathic Family Medicine. Philadelphia, PA: Lippincott, Williams \& Wilkins, Copyright 2007:208-216.

22. Appenzeller O, Oribe E. The Autonomic Nervous System: An Introduction to Basic and Clinical Concepts. 5th ed. Amsterdam, the Netherlands: Elsevier; 1997.

23. Wilard FH. Autonomic nervous system. In: Chila, AG, exec. ed. Foundations of Osteopathic Medicine. 3rd ed. Baltimore, MD: Lippincott Williams \& Wilkins; 2011:chap 10:134-161.

24. Loewy AD. Anatomy of the autonomic nervous system: an overview. In: Loewy AD, Spyer KM, eds. Central Regulation of Autonomic Function. New York, NY: Oxford University Press; 1990:chap 1:3-16.

25. Moore KL. Clinically Oriented Anatomy. 2nd ed. Baltimore, MD: Williams and Wilkins; 1985:43.

26. Moore KL. Clinically Oriented Anatomy. 2nd ed. Baltimore, MD: Williams and Wilkins; 1985:931-970.

27. Kuchera ML, Kuchera WA. Osteopathic considerations in HEENT disorders disorders. Columbus, OH: Greyden Press;2010.,

28. Nelson K.E., Allgeier J. Chapter 24: The Patient with an Upper Respiratory Infection. Somatic Dysfunction in Osteopathic Family Medicine, 2e. Wolters Kluwer, 2015.

29. Sumino R, Nozaki S, Kato M. Central pathway of trigemino-neck reflex [abstract]. In: Oral-Facial Sensory and Motor Functions. International Symposium. Tokyo, Japan: Quintessence; 1980:28.

30. Ward R, ed. Foundations for Osteopathic Medicine. 2nd ed. Philadelphia, PA: Lippincott Williams \& Wilkins, 2003.

31. Van Buskirk RL, Nelson KE. Osteopathic family practice: an application of the primary care model. In: Ward RC, exec.ed. Foundations for Osteopathic Medicine. 2nd ed. Philadelphia, PA: Lippincott Williams \& Wilkins; 2003:289-297.

32. Kuchera M, Kuchera W. Osteopathic Considerations in Systemic Dysfunction. 2nd ed. Columbus, OH: Greyden Press; 1994:38.

33. Bagai A, Thavendiranathan P, Detsky AS. Does this patient have hearing impairment? . 2006 Jan 25; 295(4):416-28. Review. PubMed PMID: 16434632.

34. Pirozzo S, Papinczak T, Glasziou P. Whispered voice test for screening for hearing impairment in adults and children: systematic review. BMJ. 2003 Oct 25; 327(7421):967. Review. PubMed PMID: 14576249; PubMed Central PMCID: PMC259166.

35. Chapman F. An Endocrine Interpretation of Chapman's Reflexes. 2nd ed. Indianapolis, IN: American Academy of Osteopathy; 1937:27.

36. Owens C. An Endocrine Interpretation of Chapman's Reflexes. 2nd ed. 1937. Indianapolis, IN: Reprinted by the Academy of Applied Osteopathy (American Academy of Osteopathy); 1963.

37. Kuchera ML, Kuchera WA. Osteopathic considerations in HEENT disorders. Columbus, OH: Greyden Press;2010., 2010.

38. Williams PL, ed. Gray's Anatomy. 38th ed. Edinburgh, UK: Churchill Livingstone; 1995:490.

39. Bjorne A. Assessment of temporomandibular and cervical spine disorders in tinnitus patients. Prog Brain research 2007; 166: 215-219.

40. Bjorne A, Agerberg G, Craniomandibular disorders in patients with Meniere's disease: a controlled study. J of Orofacial pain, 1966; 10: 28-37.

41. Bjorne A, Bevern A, Agerberg G, Odont G. Cervical signs and symptoms in patients with Meniere's disease: a controlled study. Journ of Craniomand Pract 1998; 16:194-202.

42. Degenhardt BD, Kuchera ML: The prevalence of cranial dysfunction in children with a history of otitis media from kindergarten to third grade. Mead-Johnson Fellowship Paper, 1993. 
43. Educational Council on Osteopathic Principles (ECOP) of the American Association of Colleges of Osteopathic Medicine, Glossary of Osteopathic Terminology, Chevy Chase, Revised October 2014.

44. Nicholas A.S., Nicholas E.A., Atlas of Osteopathic techniques, 3e Chapter 18: Osteopathic Cranial Manipulative Medicine. Cranial region, 2016.

45. Greenman's Principles of Manual Medicine, 5e. Chapter 12 Cranial technique. Walking Around the Temporal Bone. Lisa A. DeStefano, Wolters Kluwer, 2017.

46. Teachey WS. Otolaryngic myofascial pain syndromes. Curr Pain Headache Rep, 2004; 8:457-462.

47. Muncie $\mathrm{CH}$. Prevention and Cure of Deafness. Through Muncie Reconstructive Method. 1960.

48. Darrow DH, Dash N, Derkay CS. Otitis media concepts and controversies [review]. Curr Opin Otolaryngol Head Neck Surg. 2003;11: 416-423.

49. Holborow C. Eustachian tubal function: changes throughout childhood and neuro-muscular control. J Laryngol Otol. 1975; 89:47-55.

50. Medders G, Mattox DE. Update on otitis media: pathogenesis and diagnosis. J Respir Dis. 1988;9: 37-46.

51. Nelson K.E., Habenicht A.L., Sergueef N., Allgeier J. Chapter 16: The Geriatric Patient. Somatic Dysfunction in Osteopathic Family Medicine, 2e. Wolters Kluwer, 2015.

52. Cole WV: Disorders of the nervous system, in Hoag JM (ed.) Osteopathic Medicine. New York, McGraw-Hill, 1969, ch. 20, p 315.

53. Bjome A, Agerberg G. Reduction in sick leave and costs to society of patients with Meniere's disease after treatment of temporomandibular and cervical spine disorders: a controlled six-year cost-benefit study. Cranio 2003 Apr; 21 (2): 136-143.

54. Bjorrne A, Agerberg G, Odont G. Symptom relief after treatment of temporomandibular and cervical spine disorders in patients with Meniere's disease: a three year follow-up. The J of Craniomandib Pract, 2003; 21: 50-60.

55. Sen P. \& Papesch M.: Is there any evidence for complementary and alternative therapy in Menieres disease. The Internet Journal of Otorhinolarngology. 4(1), 2005.

56. Korr IM (ed.) The Neurobiologic Mechanisms in Manipulative Therapy. New York, Plenum Press, 1977 p61.

57. Adamek K. Osteopathic Treatment for the Symptomatic Relief of Meniere's disease (thesis). 2004. Victoria University, Melbourne. Accessed Mar 16, 2009.

58. Greenman P. Principles of Manual Medicine. 2nd ed. Baltimore, MD: Williams \& Wilkins, 1996.

59. Mitchell FL Jr. The Muscle Energy Manual, Vol 1. East Lansing, MI: MET, 1995.

60. Neumann HD. Introduction to Manual Medicine. Berlin, Germany: SpringerVerlag, 1989.

61. Nicholas A.S., Nicholas E.A., Atlas of Osteopathic techniques, 3e Chapter 10 Muscle energy. Cervical region, 2016.

62. Chila, AG, ed. Foundations of Osteopathic Medicine. 3rd ed. Baltimore, MD: Lippincott Williams \& Wilkins, 2011.

63. Nicholas A.S., Nicholas E.A., Atlas of Osteopathic techniques, 3e Chapter 14: Balanced Ligamentous Tension and Ligamentous Articular Strain Techniques. Cervical region, 2016.

64. Speece C, Crow T. Ligamentous Articular Strain: Osteopathic Techniques for the Body. Seattle, WA: Eastland, 2001.

65. Kimberly P, Funk S, eds. Outline of Osteopathic Manipulative Procedures: The Kimberly Manual. Millennium Edition. Marceline, MO: Walsworth, 2000.
66. Nicholas A.S., Nicholas E.A., Atlas of Osteopathic techniques, 3e Chapter 17: Articulatory and Combined Techniques. Cervical region, 2016.

67. Magoun HI Osteopathy in the Cranial Field. Kirksville, Journal Printing Co., 3rd ed., 1976, p 281.

68. Meador JA. Cerumen Impaction in the Elderly. Journal of Gerontologica Nursing. 1995;21(12):43-45. doi:10.3928/0098-9134-19951201-09.

69. Dibartolomeo JR. Exostoses of the External Auditory Canal. Annals of Otology, Rhinology \& Laryngology. 1979; 88(6_suppl):2-20. doi:10.1177/00034894790880s601

70. Hsiao S-H, Liu T-C. Osteoma of the External Ear Canal. Otology \& Neurotology. 2003; 24(6):960. doi:10.1097/00129492-200311000-00025

71. Nyrop M, Grøntved A. Cancer of the External Auditory Canal. Archives of Otolaryngology-Head \& Neck Surgery. 2002; 128(7):834-837. doi:10.1001/ archotol.128.7.834

72. Olszewska E, Wagner M, Bernal-Sprekelsen M, et al. Etiopathogenesis of cholesteatoma. European Archives of Oto-Rhino-Laryngology. 2004; 261(1):6-24. doi:10.1007/s00405-003-0623-x

73. Chole RA, Mckenna M. Pathophysiology of Otosclerosis. Otology \& Neurotology. 2001;22 (2):249-257. doi:10.1097/00129492-20010300000023

74. Sajjadi H, Paparella MM. Menieres disease. The Lancet. 2008; 372(9636):406-414. doi:10.1016/s0140-6736(08)61161-7.

75. Forge A, Schacht J. Aminoglycoside Antibiotics. Audiology and NeuroOtology. 2000; 5(1):3-22. doi:10.1159/000013861

76. Seffinger MA, Hruby RJ. Temporomandibular Joint Dysfunction. In: Evidence-Based Manual Medicine. A Problem-Oriented Approach. Elsevier Science, Health Science Division. 2007. pp. 207-220.

77. Feteih RM. Signs and symptoms of temporomandibular disorders and oral parafunctions in urban Saudi Arabian adolescents: a research report. Journal of Head and Face Medicine 2:25 (August 16th, 2006).

78. Nelson K.E., Allgeier J. Chapter 7: Viscerosomatic Reflexes and Somatovisceral Influences. Somatic Dysfunction in Osteopathic Family Medicine, 2e. Wolters Kluwer, 2015.

79. Travell JG, Simons DG. Myofascial pain and dysfunction: A Trigger point manual. Baltimore, Williams \& Wilkins, 1983.

80. Galbreath WO. Acute otitis media, including its postural and manipulative treatment. J Am Osteopath Assoc 1929:377-379.

81. Pratt-Harrington D. Galbreath technique: a manipulative treatment for otitis media revisited. J Am Osteopath Assoc 2000; 100:635-639.

82. Chikly B. Silent Waves: Theory and Practice of Lymph Drainage Therapy. An Osteopathic Lymphatic Technique. 2nd ed. Scottsdale, AZ: IHH, 2004.

83. Nicholas A.S., Nicholas E.A., Atlas of Osteopathic techniques, 3e Chapter 16: Iymphatic techniques. Head and Neck, 2016.

84. Jones LH, Kusunose RS, Goering EK. Jones Strain-Counterstrain. Carlsbad, CA: Jones Strain-Counterstrain, 1995

85. Myers HL. Clinical Application of Counterstrain. Tucson, AZ: Osteopathic Press, A Division of Tucson Osteopathic Medical Foundation, 2006.

86. Nicholas A.S., Nicholas E.A., Atlas of Osteopathic techniques, 3e Chapter 9: Counterstrain techniques. Temporomandibular Joint, 2016.

87. Nicholas A.S., Nicholas E.A., Atlas of Osteopathic techniques, 3e Chapter 9: Counterstrain techniques. Posterior cervical region, 2016.

88. Rennie P, Glover J. Counterstrain and Exercise: An Integrated Approach. 2nd ed. Williamstown, MI: RennieMatrix, 2004. 